\title{
Norwegian Ocean Climate Project (NOClim)
}

\section{SOLFRID S:ETRE HJøLLo}

NOClim scientific secretary; Solfrid.Hjollo@gfi.uib.no

Since July 2000, about 35 scientists from different disciplines have been working within the Norwegian Ocean Climate Project (NOClim), a project initiated to study ocean climate variability in the northern seas. The program focuses on theory and modelling of meridional oceanic heat transport and analysis of past and modern ocean climate process variability. The overall objectives of NOClim are to improve our understanding of a) rapid changes in the thermohaline circulation, b) ocean and ice processes related to climate, and mechanisms causing significant variability in the hydrography, circulation and ice cover and c) to maintain time series for early detection of climate change in the Northern seas.

For rapid and dramatic changes, i.e. essential changes in ocean circulation and ice-sheet on time scale 100 years or less, we have focused on two episodes, the Younger Dryas and Heinrich 4 about 13,000 and 40,000 years ago respectively. Efforts have been concentrated on constructing time slice maps based on various palaeoclimatic proxies from 38 sediment cores in the northern North Atlantic. The preliminary maps show low sea surface temperature (SST) for most of the area from percentage of $N$. pachyderma, but marked gradients with depleted values along continental margins and northeast of Iceland for $\delta^{18} \mathrm{O} N$. pachyderma(s). During the Younger Dryas, strong brine formation took place, and major changes in deep ocean circulation occurred. At the end of the Younger Dryas SST increased by about $5^{\circ} \mathrm{C}$ within less than a decade, consistent with earlier ice core studies.

Observations in the Greenland Sea have shown deepwater ventilation in cold core anticyclonic eddies, with lifetimes of 1 year. These reach down to $2000 \mathrm{~m}$ depth and have a radius of a few kilometres.

Instrumental and historic observations, comprising multi-decadal to century-scale timeseries from around the Nordic Seas and adjacent areas,

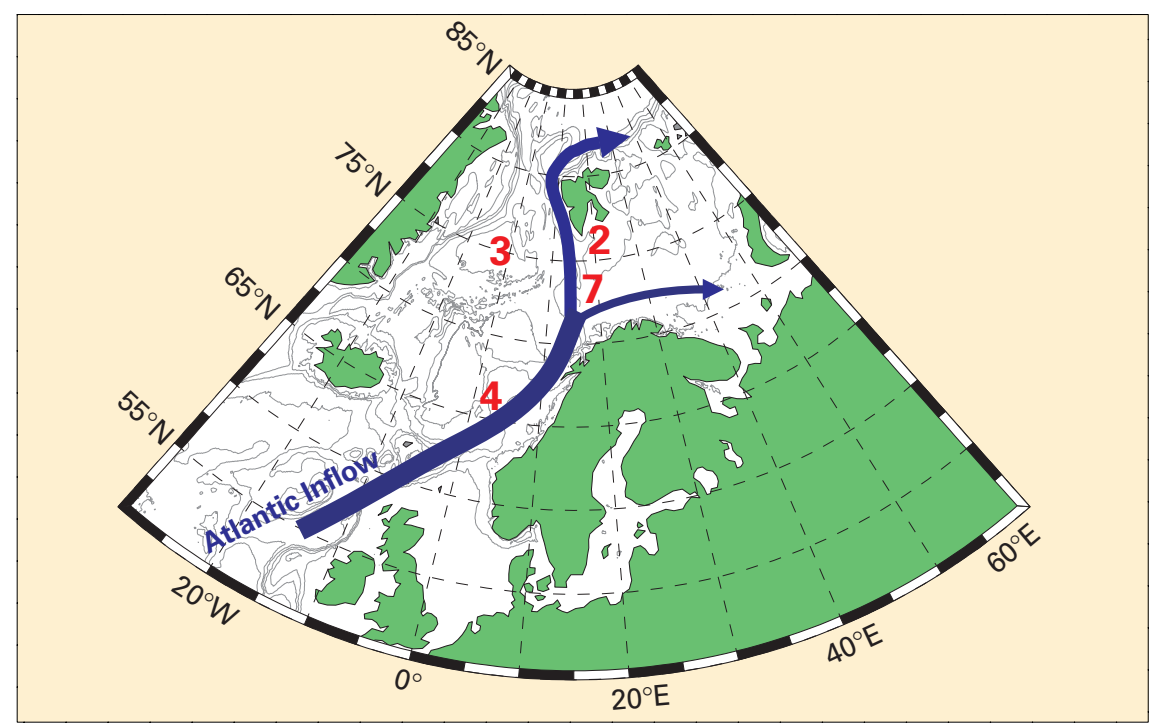

Fig. 1: Geographical working areas for specific studies in tasks 2, 3, 4, and 7 in the first phase of the project. Tasks 1, 5 and 6 will use data and model results from large parts of the entire area and are not shown on the map. Task 2 uses Storfjorden as a "laboratory" for process studies. Task 3 primarily covers the deep parts of the Nordic Seas. Task 4 deals with the front between Atlantic and Arctic Water. Task 7 addresses Atlantic inflow from the North Atlantic towards the Arctic as well as ice and freshwater flow through the Fram Strait.

have been collected as a coordinated dataset. Since the 1960s, sea level pressure from around the Icelandic Low region shows a delay of the consistent abrupt pressure rise in late February, which has contributed to the unusually positive winter NAO index values.

Paleo SST data from the Vøring Plateau show strong links to the $\mathrm{Ca}$ riaco Basin off Venezuela, indicating that northward movement of the intertropical convergence zone coincides with higher SST in the Nordic Seas. SST for the last 2000 years shows decadal-scale variability of $1-2^{\circ} \mathrm{C}$ in the Norwegian Atlantic Current and $3-4^{\circ} \mathrm{C}$ in the Irminger Current. A proxy record from Malangen, northern Norway shows a gradual warming of bottom water after $A D$ $1900\left(0.5^{\circ} \mathrm{C}\right)$.

An ensemble of multi-decadal to century-scale temperature and ice datasets in combination with global atmosphere-ocean climate modeling shows the patterns of variability in Arctic temperature and sea ice in the last two decades to be distinct from an early 20th-century warm period and indicates that recent changes are a response to greenhouse warming.

Monitoring has been concentrated on the inflow of Atlantic water into the arctic and the deepwater characteristics. In the south, the Atlantic Water flux is estimated to be $4.4 \mathrm{~Sv}$ (1 $\mathrm{Sv}=10^{6} \mathrm{~m}^{3} \mathrm{~s}^{-1}$ ) in the eastern branch and 3.4 Sv for the western branch. ADCP current meter observations in the Fugløya-Bear Island section show that during 2001 there has been a generally lower inflow to the Barents Seas. In the Fram Strait, monthly current velocity means averaged over two years show a net transport of $1.6 \pm 1.7 \mathrm{~Sv}$ to the south. The transport maximum is found in spring and the minimum in summer. During the 1990s, the maximum temperature increased in the Fram Strait and between Svalbard and Norway. The Greenland Basin type deepwater has retreated southwards during the last 20 years in the Fram Strait, and is being replaced by Eurasian Basin type water. In the central Greenland Sea, the deepwater temperature is increasing.

NOClim has been active for almost two years and, depending on further funding, will continue for another four.

More information can be found at www.noclim.org 